O "Penacho": os presidentes do Conselho de Estado e a Primeira Câmara dos Deputados por eleição direta

(1881-1884) - Alexandra do Nascimento Aguiar

\title{
O "PENACHO": OS PRESIDENTES DO CONSELHO DE ESTADO E A PRIMEIRA CÂMARA DOS DEPUTADOS POR ELEIÇÃO DIRETA (1881-1884)
}

\author{
Alexandra do Nascimento Aguiar ${ }^{1}$
}

\begin{abstract}
Resumo: O objetivo do artigo é descrever e analisar a cobertura realizada pela Revista Illustrada, referência obrigatória entre os periódicos que retratavam a sociedade da segunda metade do oitocentos, com relação aos presidentes do Conselho de Estado durante a primeira câmara da reforma eleitoral de 1881 . O principal argumento é que a sátira era utilizada pela revista como forma de exercer pressão política sobre o conselho de Estado, com o objetivo principal de colocar a questão da emancipação em pauta.
\end{abstract}

Palavras-chave: Revista Illustrada, Conselho de Estado, Lei Saraiva, Parlamento, Reforma Eleitoral.

\section{THE "PENACHO": THE PRESIDENTS OF THE COUNCIL OF STATE AND THE FIRST CHAMBER OF THE MEMBERS OF DIRECT ELECTION (1881-1884)}

\begin{abstract}
The aim of this article is to describe and analyze the Revista Illustrada`s coverage, an obligatory reference among the periodicals that analized the society of the second half of the eighteenth century, in relation to the presidents of the State Council during the first chamber after the electoral reform of 1881. The main argument is satire was used by the magazine as a way of political pressure on the Council of State, with the main objective that put the emancipation on the political agenda.
\end{abstract}

Keywords: Illustrada Magazine, State Council, Saraiva Law, Parliament, Electoral Reform.

\section{EL “PENACHO": LOS PRESIDENTES DEL CONSEJO DE ESTADO Y LA PRIMERA CÁMARA DE LOS DIPUTADOS POR ELECCIÓN DIRECTA (1881-1884)}

Resumen: El objetivo del artículo es describir y analizar la cobertura realizada por la Revista Illustrada, una referencia obligatoria entre los periódicos que retrataban la sociedad de la segunda mitad de los ochocientos, con relación a los presidentes del Consejo de Estado durante la Primera Cámara de la Reforma Electoral de 1881. El principal argumento es que la sátira era utilizada por la revista como forma de ejercer presión política sobre el Consejo de Estado, con el objetivo principal de plantear la cuestión de la emancipación en pauta.

Palabras clave: Revista Illustrada, Consejo de Estado, Ley Saraiva, Parlamento, Reforma Electoral.

\footnotetext{
${ }^{1}$ Doutora em História Política pelo Programa de Pós-Graduação em História da Universidade do Estado do Rio de Janeiro - PPGH/UERJ. Professora da Rede Estadual de Educação do Rio de Janeiro - SEED/RJ.
} 
O "Penacho": os presidentes do Conselho de Estado e a Primeira Câmara dos Deputados por eleição direta (1881-1884) - Alexandra do Nascimento Aguiar

\section{INTRODUÇÃO}

A reforma eleitoral de 1881 tem sido abordada, na historiografia, pela exclusão da maioria da população devido à exigência de alfabetização para participação eleitoral e por introduzir o voto direto no Brasil (HOLANDA, 2008; CARVALHO, 2008; GRAHAM, 1997). Interessa-nos, no presente artigo, o olhar da Revista Illustrada sobre a relação entre o governo, na figura do Presidente do Conselho de Estado, e esta primeira Câmara dos Deputados por eleição direta.

Realizada pelo Partido Liberal e orientada por José Antônio Saraiva, a reforma eleitoral de 1881 foi aprovada sob o discurso de obstar as práticas ilegais, as interferências do governo e a formação de Câmaras unânimes que caracterizavam as eleições imperiais. Buscava-se, assim, a autenticidade do sistema representativo com eleições mais livres e representação dos dois partidos. Pode-se afirmar que a Lei Saraiva foi bem sucedida nesta primeira execução, pois, pela primeira vez situação e oposição dividiriam o Plenário: o Partido Liberal, com 75 parlamentares, e Partido Conservador e seus 47 deputados eleitos. No entanto, esse ambiente de convivência partidária foi marcado por embates intrapartidários e entre os dois partidos e, especialmente, por coalizões que minaram a governabilidade do Partido Liberal.

Tal cenário foi acompanhado pela Revista Illustrada, referência obrigatória entre os periódicos que retratavam a sociedade da segunda metade do século XIX. Criada por Ângelo Agostini, em 1876, a Revista Illustrada se distinguiu por associar texto, desenhos e humor na defesa da bandeira abolicionista e por abordar de forma satírica as personalidades públicas e a vida política na Corte. Homens de Estado, deputados, senadores eram notabilizados nas páginas e na capa do periódico como personagens, cujo palco era o Plenário, o Senado, as salas de jantar de medalhões, espaços onde eram tomadas as decisões sobre o dia-a-dia do país.

A decepção com os resultados da Lei Saraiva, as mazelas e as disputas do cotidiano parlamentar, a frustração com os programas de governo e as obstruções e dissensões em torno das iniciativas pela emancipação dos escravos compõem o quadro político criado a partir da reforma eleitoral de 1881. Essa percepção se evidencia através das representações sobre os Presidentes do Conselho de Estado nas capas da Revista Illustrada, aqui analisadas como reações aos discursos dos chefes de governo e à sua relação com a nova Câmara, no decorrer da legislatura 1881-1884. 
O "Penacho": os presidentes do Conselho de Estado e a Primeira Câmara dos Deputados por eleição direta (1881-1884) - Alexandra do Nascimento Aguiar

O Conselho de Estado $^{2}$ foi, inicialmente, proposto como órgão com função políticoadministrativa, formado por diferentes orientações políticas (MARTINS, 2007, p. 23), no entanto, não há consenso sobre seu efetivo papel político, "cérebro da monarquia" (CARVALHO, 2008, p. 357) devido à sua composição por uma elite política homogênea ou como a "materialização do Poder Moderador" (MARTINS, 2006).

O cargo de Presidente do Conselho foi criado pelo decreto $\mathrm{n}^{\circ} 523$ de 20 de julho de 1847, com Manuel Alves Branco como o primeiro nomeado. As demais nomeações por D. Pedro II variaram de acordo com o partido eleito em maioria na Câmara, cuja vitória ocorria através de manipulações do processo eleitoral desde os ministérios até os municípios, ou conforme o tipo de política que o Imperador pretendia implementar. Este foi o caso da reforma da eleição direta, motivo pelo qual foi nomeado um Gabinete presidido pelo Partido Liberal, que a partir de 1878 alcançou maioria nas urnas, e continuaria com José Antônio Saraiva até a efetivação da reforma eleitoral, que demitiu-se em 1882 quando a considerou como concluída. Sobre os Presidentes do Conselho seguintes à Saraiva havia a expectativa de que dariam continuidade ao programa de reformas do Partido Liberal e que incluía a emancipação.

\section{MARTINHO CAMPOS: UM CONSERVADOR NO PARTIDO LIBERAL}

D. Pedro II convidou Martinho Álvares da Silva Campos para a presidência do Conselho de Estado no momento em que movimento abolicionista cobrava novas medidas contra a escravidão. Martinho foi escolhido para o cargo porque tranquilizava os ânimos, pois era um nome "aceitável para muitos liberais, por ser um deles, mas inimigo de qualquer alteração no estatuto do trabalhador escravo" (HOLANDA, 2008, p. 125-126), e possuía inserção entre os conservadores. Tanto que no dia de sua nomeação como Presidente do Conselho, Martinho teria ido à casa de Paulino José Soares de Souza, liderança do Partido Conservador na Província do Rio de Janeiro, portanto, chefe da oposição, para informa-lo sobre a boa nova: “-Então snr. Martinho, como foi isso? -É verdade, Snr, Paulino, o

\footnotetext{
2 O Conselho de Estado foi inspirado nos secretários palacianos convertidos em conselheiros a partir da "Viradeira" (PEDREIRA, COSTA, 2008, p. 42-44) em Portugal, e nos conselhos áulicos das demais monarquias europeias. No Brasil, o Conselho de Estado foi adotado por Pedro I, logo após a Independência, e elaborou a Constituição de 1824, em substituição ao projeto rejeitado da Assembleia de 1823. Com as reformas do Ato Adicional de 1834, o Conselho de Estado foi extinto até 1841, quando foi restabelecido pelo Partido Conservador, no quadro da antecipação da Maioridade de Pedro II.
} 
O "Penacho": os presidentes do Conselho de Estado e a Primeira Câmara dos Deputados por eleição direta

imperador entregou o penacho ${ }^{3}$ (risadas) e a minha primeira visita é esta: vim receber as ordens do meu chefe (grandes risadas, abraços)". (SOUSA, 1923, p. 117)

$\mathrm{Na}$ visão do deputado estreante Afonso Celso (PL-MG) ${ }^{4}$, o programa de governo de Martinho Campos desapontou os correligionários, "quanto às ideias, que decepção! Não cogitava de nenhuma das apregoadas reformas liberais". A legenda na capa da Revista Illustrada sobre o chefe de governo, "quem aceitou o penacho foi o Sr. Martinho. S. Ex. compromete-se a por meio do bacalhau pôr tudo fora de seus eixos", indica o descompasso entre suas ideias e o programa esperado do governo liberal.

\section{Figura 1}

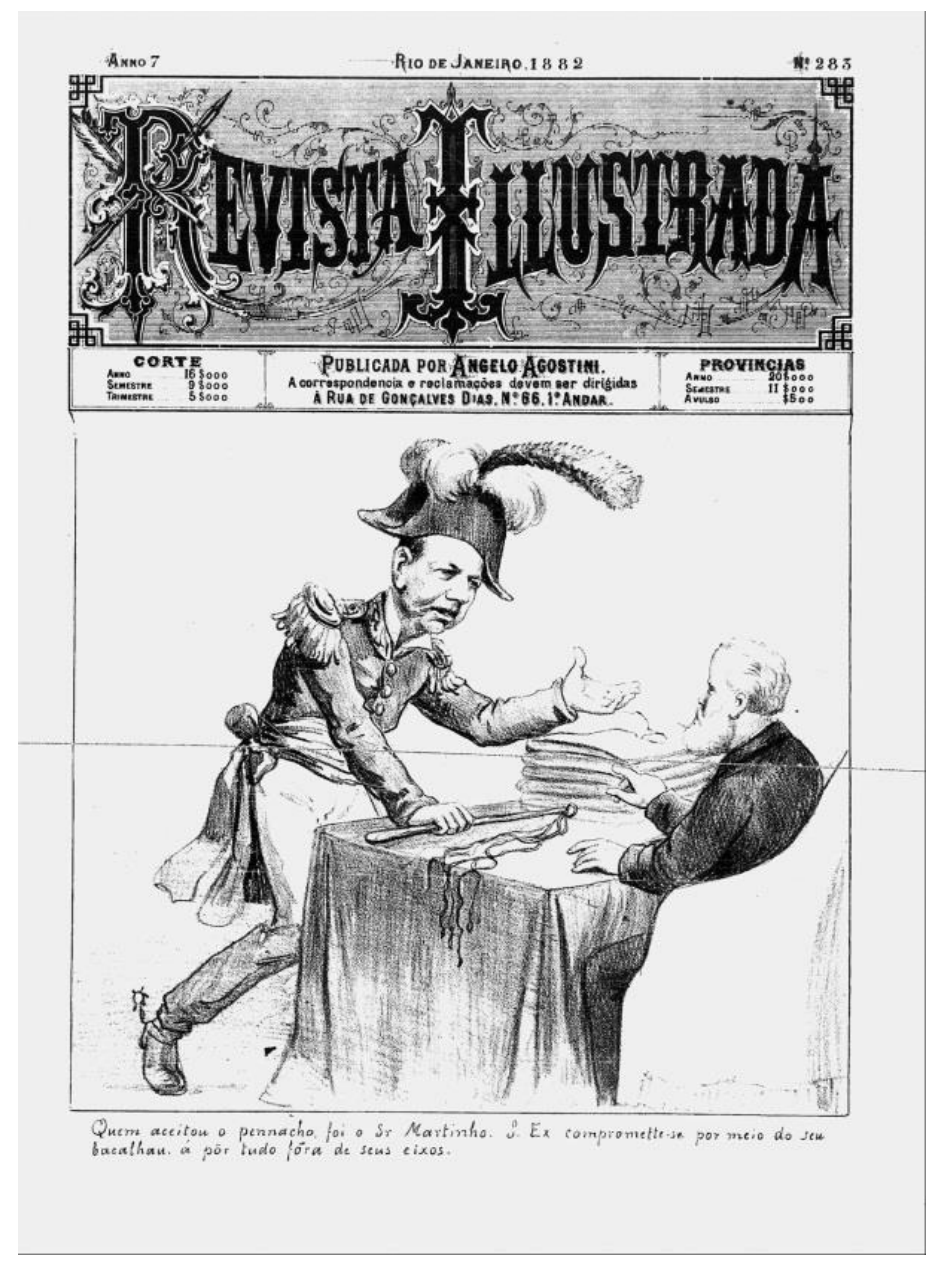

Fonte: Revista Illustrada, ano 7, 1882, $\mathrm{n}^{\circ} 283$.

\footnotetext{
${ }^{3}$ O termo "penacho", utilizado como parte do título deste artigo, é uma expressão da época que indica o poder atribuído a determinado cargo. O termo também é encontrado no periódico $O$ Conservador, 24 de fevereiro de 1882, referindo-se novamente à Martinho Campos: “... o Sr. Martinho Campos pela inglória pretensão de ter o penacho governamental por mais alguns dias..."

${ }^{4}$ Os nomes dos deputados serão seguidos da filiação partidária, PL para Partido Liberal e PC para Partido Conservador, e da sigla da província representada.
} 
O "Penacho": os presidentes do Conselho de Estado e a Primeira Câmara dos Deputados por eleição direta

Em seu discurso de apresentação como Presidente do Conselho, Martinho aludiu aos dez anos em que seu partido esteve na oposição e, por isso, estava "mais acostumado a embaraçar os governos do que a pensar em ser governo". Segundo Martinho, ainda que o papel de situação fosse mais difícil, ser oposição significava ser "mais patriótico", porque exigia "mais sacrifícios pessoais"5. A fala provocou protestos dos deputados do Partido Conservador no Parlamento e foi ironizada pela Revista Illustrada, que retratou Martinho entre as diversas "pancadas" que levaria como governo: "Foi martelo por mais de 20 anos e hoje é bigorna, mas pouco se incomoda com isso; S. Ex. ${ }^{a}$ já disse que são pancadinhas de amor! É um grande pândego o tal snr. Martinho”.

Figura 2

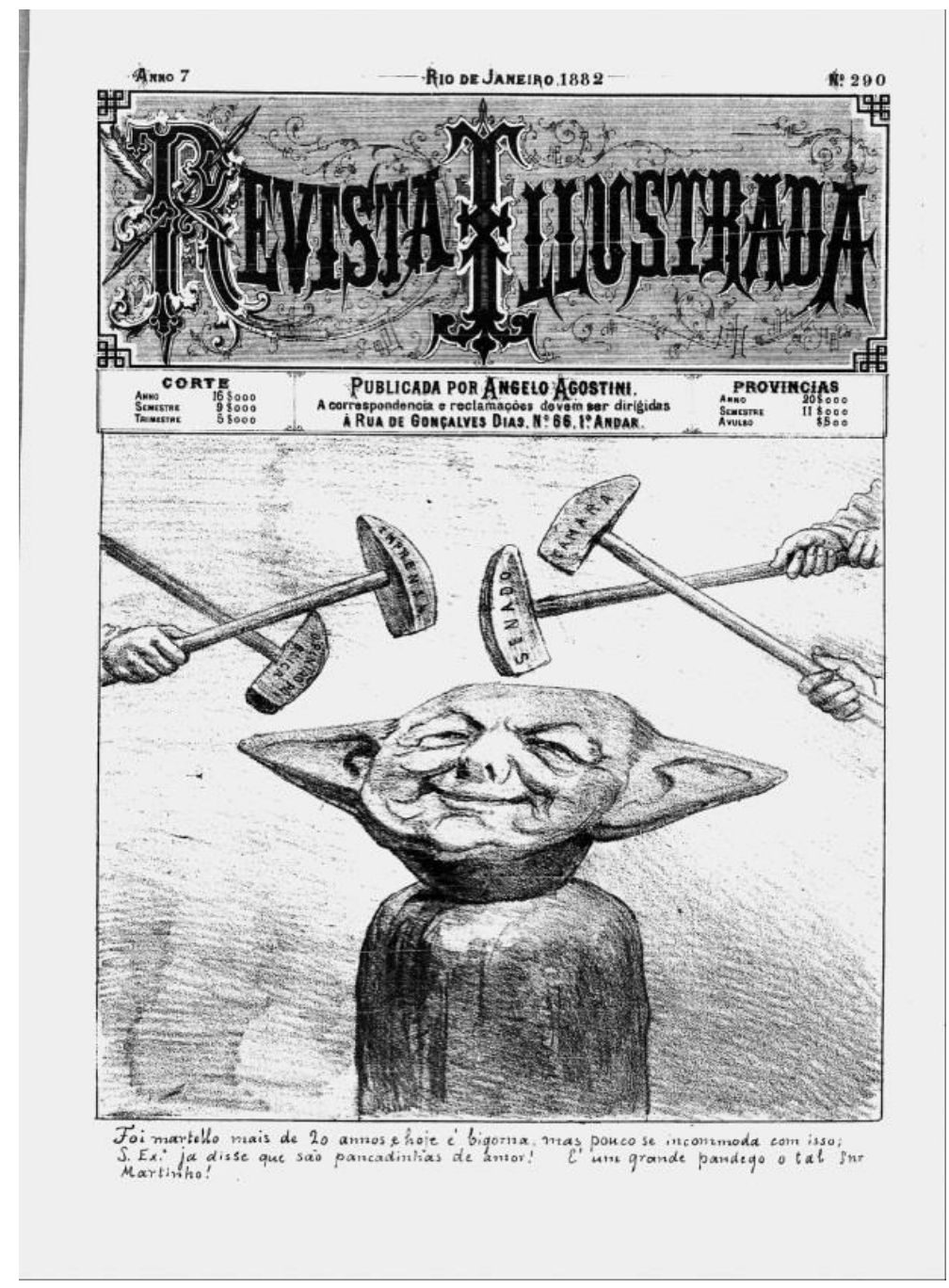

Fonte: Revista Illustrada, ano 7, 1882, nº 290.

\footnotetext{
${ }^{5}$ Anais da Câmara dos Deputados, 24 de janeiro de 1882.
} 
O "Penacho": os presidentes do Conselho de Estado e a Primeira Câmara dos Deputados por eleição direta

O periódico ressaltou o escravismo de Martinho Campos associando-o ao bacalhau, nome dado ao chicote de couro usado para torturar os escravizados, e à freguesia de Cebolas, onde possuía fazenda na província fluminense, fortemente ligada à escravidão. A Revista Illustrada também ironizou a maneira de Martinho Campos lidar com seu próprio governo, apelidado pelo próprio de "canoa" e em que, segundo ele, cabiam liberais, conservadores e republicanos sem divergências. A expressão se tornou anedota entre os parlamentares que faziam piadas como "não entre na canoa", "a canoa não pode com tanta gente", e inspirou "A canoa do Martinho - paródia ao Navio Negreiro de Castro Alves”, no qual o autor, sob pseudônimo, criticava os políticos que se calavam ou rejeitavam os debates sobre a abolição durante a presidência de Martinho Campos, em 1882, ano da publicação do poema satírico.

\section{Figura 3}

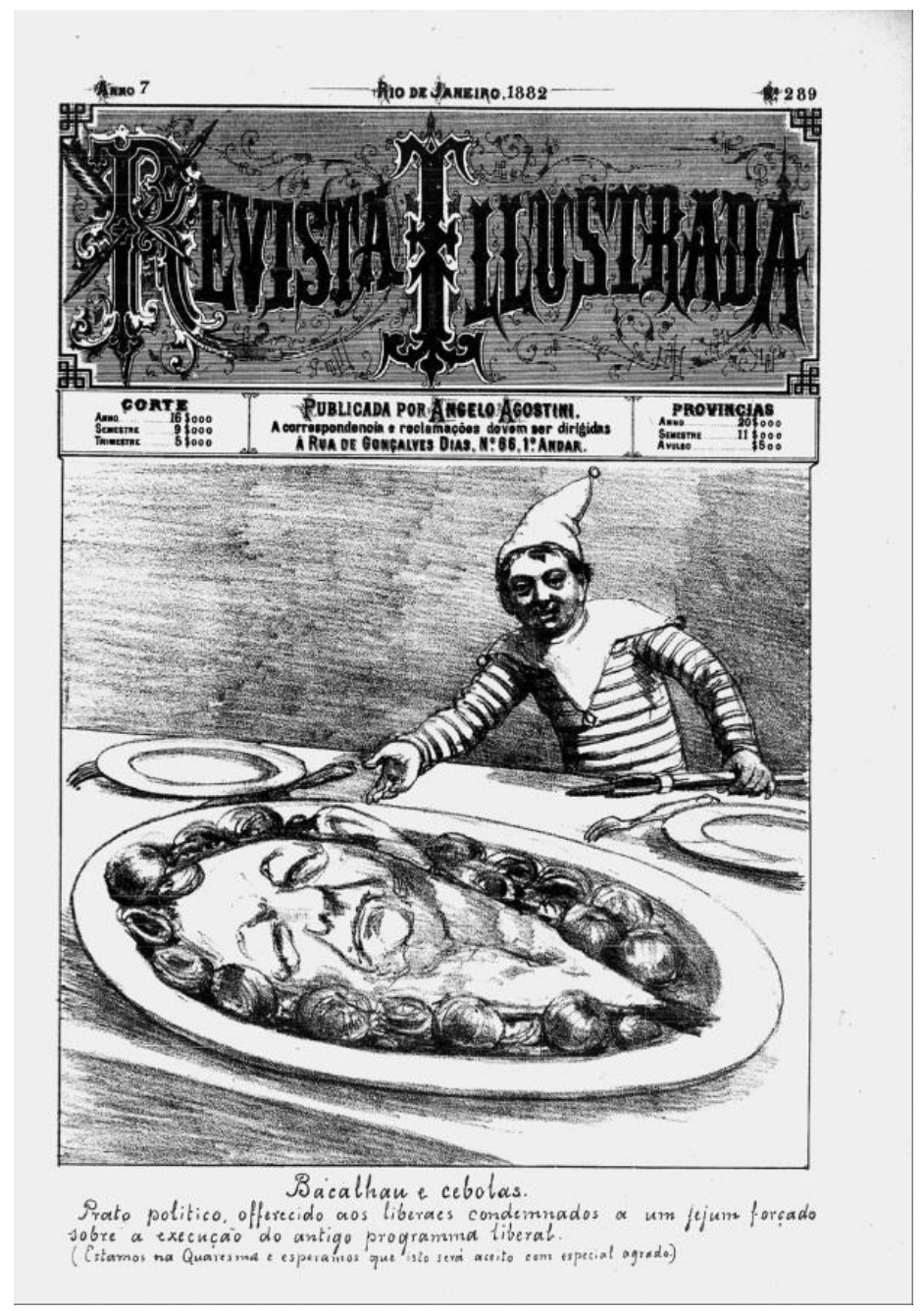

Fonte: Revista Illustrada, ano 7, 1882, nº 289. 
O "Penacho": os presidentes do Conselho de Estado e a Primeira Câmara dos Deputados por eleição direta (1881-1884) - Alexandra do Nascimento Aguiar

No número 289, o periódico destaca a ausência do programa liberal, substituído pelo "prato político", ou seja, Martinho Campos, em seu primeiro discurso na presidência, declarou que seu governo se dedicaria exclusivamente à economia, por isso não faria as reformas do judiciário, políticas, administrativas e do trabalho escravo. Portanto, não levaria adiante o programa de seu partido. Campos também chamou atenção sobre a desmoralização da política como uma injustiça contra a categoria, "mal vista há algum tempo" pela população que não compreendia que os políticos serviam ao Brasil como "mártires da pátria".

O ministério de Martinho Campos sobreviveu por cinco meses e se viu questionado pela imprensa sobre o programa com tendência conservadora e o afastamento das reformas apregoadas pelo Partido Liberal em 1869. Lafayette Rodrigues Pereira, que será indicado à Presidência do Conselho em breve, confidenciaria ao irmão, em abril de 1882, que a queda do Gabinete era aguardada, "o homem está à espera de um motivo para não ficar claro que cai por incapacidade. É fora de dúvida que o ministério sucessor será ainda liberal. Teremos, pois, Paranaguá ou Saraiva" (PEREIRA, 1968, p. 112-113).

A pressão contra Martinho Campos cresceu quando Martim Francisco Ribeiro de Andrada (PL-SP) se exonerou da presidência da Câmara por discordar da orientação antirreformista do governo, iniciando uma dissidência no partido. Martinho alegava que a urgência de problemas financeiros do país tornava tais reformas inoportunas. A indecisão sobre realizar a revisão da reforma eleitoral, cobrada pelos parlamentares dos dois partidos após denúncias de irregularidades nas eleições, contribuiu para que ele perdesse apoio também dos conservadores.

O golpe derradeiro ocorreu quando Inácio Martins (PL-MG) entregou o requerimento do projeto de revisão do alistamento eleitoral, exigindo que este fosse discutido no dia seguinte. Feita a votação, 63 deputados foram favoráveis e 45 contrários $^{6}$. A expectativa de Martinho Campos sobre contar com a bancada conservadora foi malograda, pois, esta se uniu à dissidência liberal exigindo a revisão da Lei Saraiva. Liberais e conservadores formaram maioria contra o presidente do Conselho que preferiu se demitir (PEREIRA DA SILVA, 2003, p. 33).

\footnotetext{
${ }^{6}$ Anais da Câmara dos Deputados, 30 de Junho de 1882.
} 
O "Penacho": os presidentes do Conselho de Estado e a Primeira Câmara dos Deputados por eleição direta (1881-1884) - Alexandra do Nascimento Aguiar

\section{JOÃO LUSTOSA DA CUNHA PARANAGUÁ: A BANDEIRA DO PARTIDO LIBERAL DE 1869}

Com a saída de Martinho Campos da presidência do Conselho, Pedro II queria que Saraiva reassumisse o cargo, porém com a recusa deste, voltou a convidar João Lustosa da Cunha (visconde de Paranaguá). O novo programa apresentado pelo visconde de Paranaguá confirmou, por um lado, as expectativas e, por outro, os receios dos parlamentares. Logo de início ele afirmou que seu governo seguiria a programa do partido de 1869: a independência do judiciário, a descentralização administrativa, a ampliação da instrução pública e a transição do trabalho escravo para o livre. Ressaltando que, nesta última, o governo não adotaria a abolição imediata, contudo faria algo nesse sentido para adequar o Brasil ao seu tempo, que não admitia mais a escravidão.

$\mathrm{O}$ respeito à propriedade seria preservado através de medidas cautelosas de continuidade da Lei do Ventre Livre e outras providências como a elevação do fundo de emancipação, o imposto sobre transmissão de escravos e a proibição do comércio interprovincial ${ }^{7}$. Paranaguá encerrou sua fala com uma mensagem implícita aos conservadores, referindo-se à convocação de Paulino José Soares de Souza pelo imperador para explicar a coalizão na Câmara contra ministério de Martinho Campos.

O próprio Paulino foi o primeiro a comentar o discurso do novo Gabinete, respondendo a provocação do presidente do Conselho. O relato sobre a crise no Gabinete de Martinho Campos demonstra que a influência do político conservador ultrapassava a posição de chefe de partido na província fluminense, porém era uma liderança política de ampla atuação. Segundo ele, fora convidado ao lado de Martinho Campos pelo imperador para que falassem sobre o conflito entre o Gabinete e a Assembleia. Em sua opinião, não houve coalizão, mas "coincidência" entre duas partes heterogêneas, a dissidência liberal e os conservadores, contra o grupo que permaneceu com Martinho Campos, portanto, "três minorias" que inviabilizariam a continuidade daquela Câmara ${ }^{8}$. Pode-se supor, a partir da fala de Paulino e de sua proximidade com Martinho, a intenção dos conservadores de forçar a dissolução da Câmara que, consequentemente, conduziria a novas eleições em que esperavam voltar como maioria.

A influência perturbadora do Partido Conservador naquela Câmara, ainda que minoria nas urnas, já havia sido observada pela Revista Illustrada, com a entrada de Martinho

\footnotetext{
${ }^{7}$ Anais da Câmara dos Deputados, 05 de julho de 1882.

${ }^{8}$ Ibid. 
O "Penacho": os presidentes do Conselho de Estado e a Primeira Câmara dos Deputados por eleição direta

(1881-1884) - Alexandra do Nascimento Aguiar

Campos. Tal percepção foi demonstrada na capa do periódico através do desenho de um gato, em cujo corpo estava escrito conservador, brincando com um rato, o governo.

\section{Figura 1}

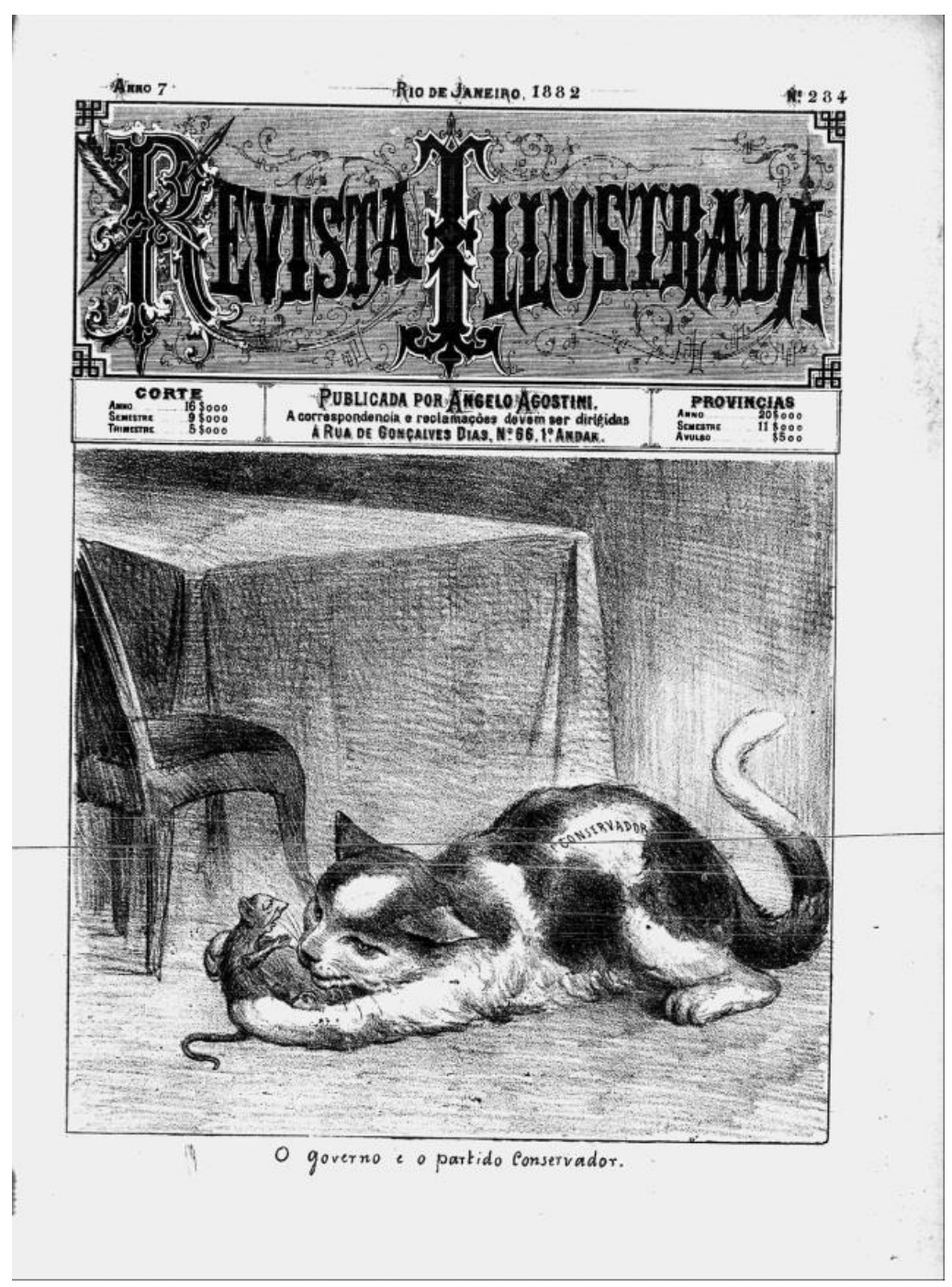

Fonte: Revista Illustrada, ano 7, 1882, nº 284.

Paulino lembrou que a oposição estava presente nesta Câmara e influiria na aprovação do orçamento, que ele via como mais relevante do que os temas de governo apresentados por Paranaguá. Era recorrente que o presidente do Conselho acumulasse o ministério da Fazenda e uma das atribuições da pasta, pela Constituição de 1824, era a submissão do balanço da receita e da despesa do Tesouro Nacional, do ano anterior, ao Parlamento assim que este se reunisse ${ }^{9}$. Mas, a tarefa não era simples, pois a aprovação do orçamento era utilizada pelo

\footnotetext{
${ }^{9}$ Art. 171 e 172. Constituição Política do Império de Brasil (25 de março de 1824).
} 
O "Penacho": os presidentes do Conselho de Estado e a Primeira Câmara dos Deputados por eleição direta

Legislativo para pressionar o Executivo, além de envolver tributações contestadas como prejudiciais por determinados grupos, como exemplo, os impostos sobre escravos mencionados por Paranaguá. O debate sobre a lei de orçamento motivava desentendimento entre o público e o privado (CARVALHO, 2008, p. 263-264), pois os deputados agiam como membros das duas esferas, representando interesses conflitantes.

Desde o início, o gabinete Paranaguá foi combatido pela oposição por adotar a bandeira partidária de 1869 e, ainda que tenha favorecido os correligionários empregando-os nas comissões, alijando os conservadores, não obteve o apoio da Câmara. Diante da ausência de apoio dos correligionários, as reformas não eram colocadas em debate ou ficavam paralisadas. A dificuldade de Paranaguá para implementar o programa do Partido Liberal também foi figurada na capa do periódico, que retratou a morosidade do governo como uma tartaruga cavalgada pelo Presidente do Conselho.

\section{Figura 5}

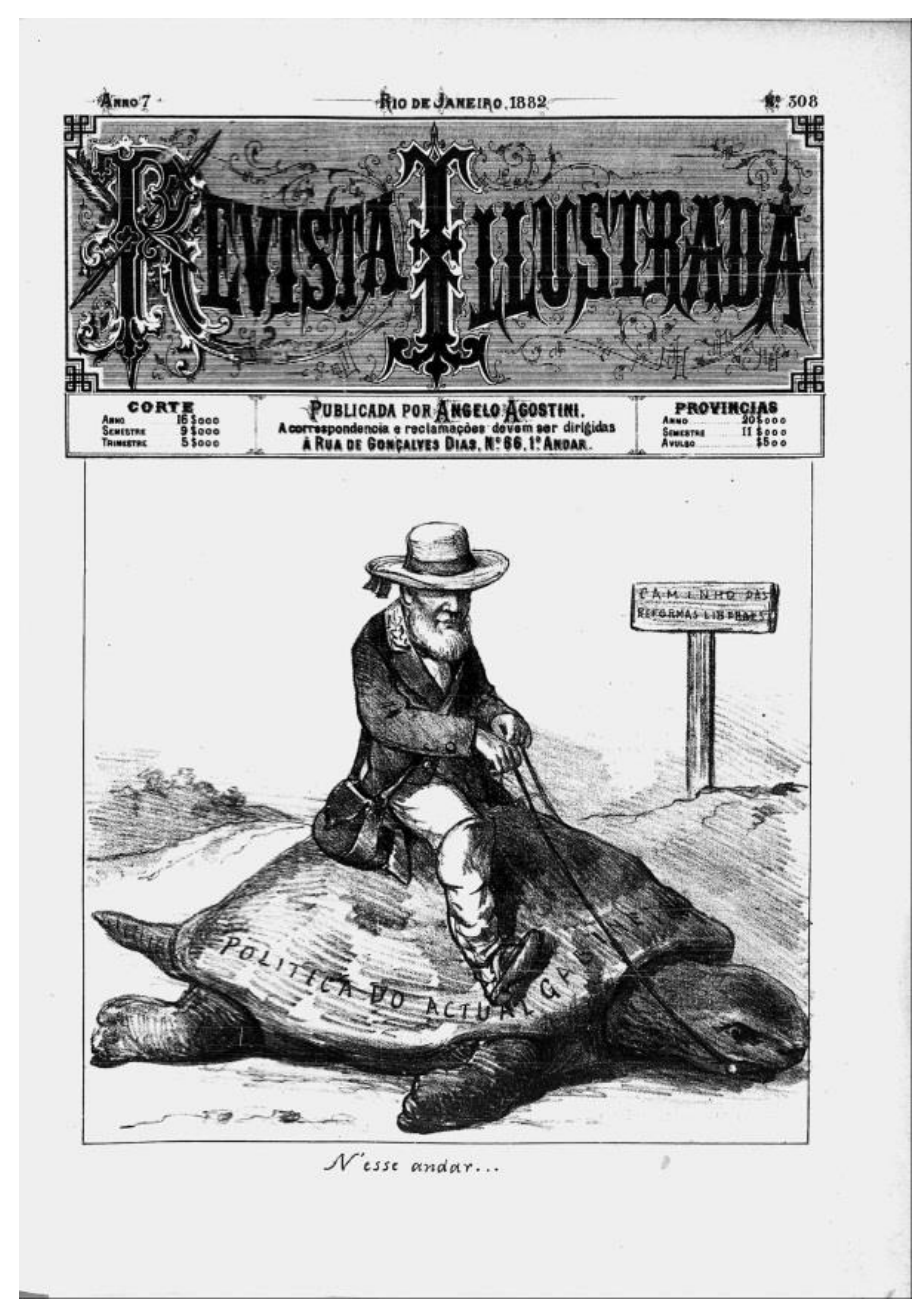

Fonte: Revista Illustrada, ano 7, 1882, nº 308. 
O "Penacho": os presidentes do Conselho de Estado e a Primeira Câmara dos Deputados por eleição direta

(1881-1884) - Alexandra do Nascimento Aguiar

A estabilidade do governo foi ameaçada por nova dissidência formada por grupos insatisfeitos sobre os impostos considerados inconstitucionais pelo Gabinete e aprovados pelas Assembleias Provinciais (PEREIRA DA SILVA, 2003, p. 514). José Mariano Carneiro da Cunha (PL-PE) reclamou sobre a decisão de revogação de tais impostos e sua substituição pelo auxílio do governo central, de acordo com a necessidade da província. Medida que contrariava a autonomia provincial desejada pelos liberais. Diante dessa ambiguidade do governo, o deputado censurava aquela Câmara, qualificando-a como Câmara unânime e afirmava que os colegas governistas votavam com a oposição para evitar derrotas. E questionava:

Tenho o direito de perguntar se o governo ainda vive [...]. Faço essa pergunta para que fique bem acentuado, para que o país saiba se o governo está moribundo, se morreu, ou pelo contrário, se fortaleceu-se ainda mais, alijando uma pesada carga que ameaçava o naufrágio do barco (risos e apartes) ${ }^{10}$.

José Mariano acusou o governo de agir como não-governo e finalizou com o requerimento que exigia explicações do governo sobre a revogação dos impostos “denominados inconstitucionais" e, após acalorado debate entre os ministros presentes e o deputado, o requerimento foi convertido em questão de confiança, com vozes de "voto, votos!" pelos deputados. A decisão foi tomada por voto nominal, pedido por Moreira de Barros (PL-SP), e 53 deputados votaram a favor do requerimento enquanto 40 votaram contra. As bancadas conservadoras silenciaram, como observou o deputado mineiro Afonso Celso Jr, "silêncio precursor de uma tempestade para o país" desagradou os deputados interessados em preservar impostos e privilégios de suas províncias, incluindo liberais, e esse conflito levou à queda do ministério (PEREIRA DA SILVA, 2003, p. 514).

\section{LAFAYETTE RODRIGUES PEREIRA: UM REPUBLICANO NO PARTIDO LIBERAL}

O terceiro ministério foi presidido por Lafayette Rodrigues Pereira, que não havia sido a primeira opção de Pedro II, ele havia convidado Saraiva pela segunda vez, que declinou e preferiu não fazer indicações. Paranaguá, então, sugeriu ao Imperador o nome de José

\footnotetext{
${ }^{10}$ Anais da Câmara dos Deputados, 14 de maio de 1883.
}

11 Ibid. 
O "Penacho": os presidentes do Conselho de Estado e a Primeira Câmara dos Deputados por eleição direta (1881-1884) - Alexandra do Nascimento Aguiar

Bonifácio, que também recusou e recomendou Manuel Pinto de Sousa Dantas como capaz de organizar um Gabinete forte. Mas este também se negou e apontou possíveis nomes: Silveira Martins, Sinimbu, Afonso Celso e Lafayette, o último foi o escolhido para a presidência. Mais uma negativa, Pedro II teria que entregar o governo aos conservadores, pois este estava sem direção há dez dias, motivo suficiente para derrubar os liberais (KOSERITZ, 1980, p. 82).

O programa apresentado por Lafayette visava agradar às duas composições da Câmara, priorizava a crise econômica ${ }^{12}$, principal crítica dos conservadores, e a descentralização, reivindicação dos correligionários. Ele reconheceu o incremento das despesas públicas pelo governo de seu próprio partido, justificando-o pela introdução de melhoramentos, e propôs como solução aumentar a receita através de cortes de gastos e não pelo aumento de impostos. Quanto à descentralização, defendia-a como demanda dos municípios e das províncias, cujas questões eram específicas e distintas do país como um todo. Por isso, submeteria um projeto de reforma administrativa à Câmara, observando a preservação dos vínculos que prendem as duas esferas do Estado ${ }^{13}$.

Sobre a reforma judiciária, percebia a necessidade de estabelecer regras que garantissem a autonomia dos magistrados, isto se daria através da promoção por antiguidade, um critério de avaliação "fora das paixões humanas”. Para a educação pública, Lafayette Rodrigues Pereira repetia a promessa dos demais de dedicar atenção ao problema que qualificou como "uma agitação pacífica" há alguns anos. Finalizou reafirmando que o governo pretendia adotar medidas auxiliares à Lei de 28 de Setembro de 1871, levando a questão servil para o centro do debate. Mencionou ações como a localização de escravos nas províncias, o aumento dos recursos para o fundo de emancipação e a criação de um imposto especial sobre o escravo. Não havia solução definida e o conjunto seria apreciado pelo Legislativo $^{14}$.

O nome de Lafayette Pereira foi rejeitado desde o início pelos parlamentares da oposição, que o consideravam inexperiente para ser nomeado Presidente do Conselho. Augusto Olímpio Gomes de Castro (PC-MA) foi o primeiro a se manifestar sobre a apresentação de Lafayette. O deputado da oposição destacou as sucessivas recusas pelos chefes liberais em assumir o governo. Pedro II já havia demonstrado impaciência diante de tais negativas, levando-o a pressionar o último Presidente, “diga aos seus amigos que o país

\footnotetext{
${ }^{12}$ Em 1878, em carta escrita ao seu irmão, Lafayette dizia que o Tesouro Público estava falido e pedia que ele mantivesse segredo sobre a informação.

${ }^{13}$ Anais da Câmara dos Deputados, 26 de maio de 1883.

${ }^{14}$ Ibid.
} 
O "Penacho": os presidentes do Conselho de Estado e a Primeira Câmara dos Deputados por eleição direta (1881-1884) - Alexandra do Nascimento Aguiar

não pode ficar sem governo". O motivo desta resistência era a falta de confiança nos deputados do próprio partido. Os liberais tentavam se segurar no governo através de sua principal obra, a reforma eleitoral, porém, as divisões internas inviabilizavam uma governabilidade. Esse quadro foi explorado por Gomes de Castro para reforçar a imagem de um governo liquidado, e desafiava os adversários, "a Câmara dos Srs. Deputados que sustenta o governo ou se é o governo que sustenta a Câmara dos Srs. Deputados?”. Era um cenário político de incertezas e Gomes de Castro expôs a rachadura no partido governista:

[Martinho Campos] Foi a negação de todas as reformas. Quando levantou aqui a voz o nobre deputado por Minas [Afonso Celso Junior], fazendo apologia à República, mas prometendo apoio ao gabinete; o nobre presidente do conselho [...] dizia: aceito o apoio, mas vivemos tão bem sob o regime desta república monárquica, que não é preciso mudar de sistema. (risos)

[...] O nobre deputado pela Bahia pedia a modificação do regime administrativo e econômico das províncias e dos municípios, medidas que o nobre presidente do conselho atual incluía no longo rol de suas reformas e o presidente do conselho do gabinete de 21 de janeiro declarava que tinha sido vereador no lugar da sua residência e que durante o exercício das funções daquele cargo sentiu muita precisão de dinheiro, mas nenhuma precisão de atribuições, por isso não havia necessidade de reformas (risos) ${ }^{15}$.

Lafayette havia relegado a bandeira partidária que Paranaguá, seu antecessor, se comprometera a efetivar. A fala do deputado Domingos de Andrade Figueira (PC-RJ) também destacou o vazio no governo dos liberais após a implantação da eleição direta, e essa lacuna propiciava aos conservadores espaço para que se apresentassem como solução. Voltando-se para o tema escravidão, também abordado por Lafayette, o deputado fluminense interpelou sobre como o governo pretendia lidar com o problema sem taxar os proprietários? Já que o próprio havia anunciado que não recorreria ao aumento tributário. O deputado concluiu afirmando que o Partido Liberal tinha ideias muito vagas que sequer mereciam atenção, e as outras mais sérias não sairiam das pastas das comissões e, neste último caso, possivelmente, referia-se à emancipação,

$\mathrm{O}$ orador já se manifestou na tribuna quando às medidas sobre o elemento servil, e há de manifestar-se sempre contra tais restrições pérfidas sobre uma propriedade reconhecida por lei.

Se os liberais têm coragem de querer resolver imediatamente o problema do elemento servil, declarem-se abolicionistas francamente, mas este procedimento às arteiras de tirar o valor da propriedade para a emancipação, jamais merecerá o apoio do orador (muito bem) ${ }^{16}$.

\footnotetext{
${ }^{15}$ Ibid.

${ }^{16}$ Ibid.
} 
O "Penacho": os presidentes do Conselho de Estado e a Primeira Câmara dos Deputados por eleição direta

O ano de 1884 foi palco do revigoramento abolicionista, que ganhou as ruas da capital e conquistou mais adeptos tornando-se causa popular. A adesão era visível na presença de multidões nas manifestações em espaços públicos pelo fim da escravidão e no apoio ao ativismo que consumia panfletos, frequentava peças teatrais, aplaudia ações de libertação e hostilizava políticos escravistas confessos (ALONSO, 2015). A Revista Illustrada comemorou essa nova fase do movimento e que foi marcada pela troca de presidência do Conselho: Lafayette Pereira pendurava sua casaca e havia a expectativa de que o novo chefe de governo - Dantas era o nome aguardado - faria ressurgir no Parlamento o debate sobre medidas mais efetivas para extinguir o trabalho escravo.

Figura 6

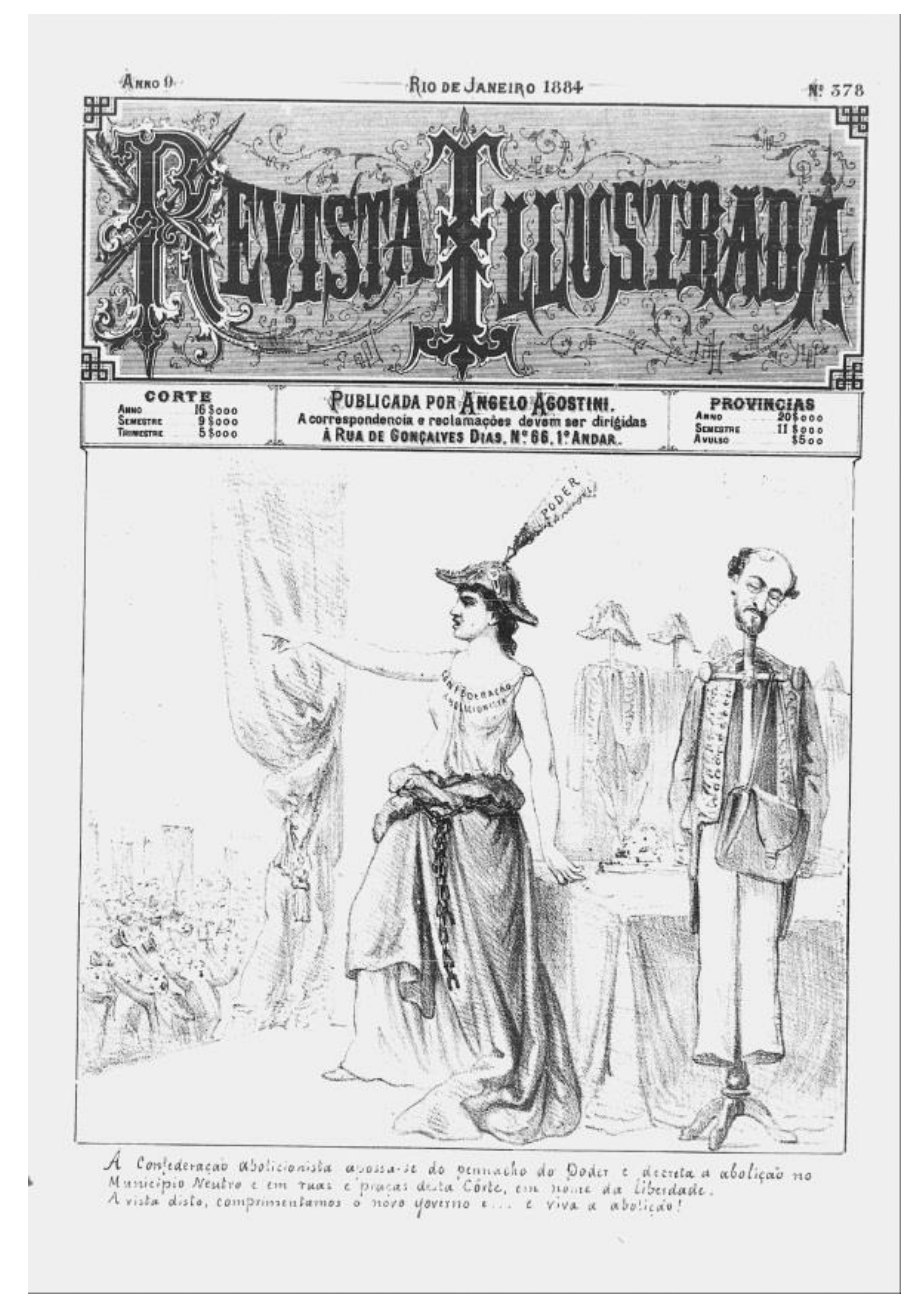

Fonte: Revista Illustrada, ano 9, 1884, nº 378.

Durante o ministério de Lafayette, dois incidentes contribuíram para seu isolamento na Câmara, levando-o a decidir pela demissão. Um deles foi o assassinato de Apulcro de Castro, 
O "Penacho": os presidentes do Conselho de Estado e a Primeira Câmara dos Deputados por eleição direta

(1881-1884) - Alexandra do Nascimento Aguiar

proprietário do pasquim Corsário, voltado para publicações sobre escândalos envolvendo nomes influentes. Apulcro de Castro foi morto à tiro por militares à paisana e o evento foi acompanhado pela opinião pública, que viu a visita de Pedro II ao quartel dos suspeitos do crime com maus olhos, projetando a atitude do Imperador no ministério vigente.

O outro episódio foi provocado pelo próprio Lafayette que, insatisfeito com o desempenho do ministro da guerra, Antônio Joaquim Rodrigues Junior, demitiu-o, externando que o considerava inapto para o cargo. A carta demissionária foi lida pelo próprio Antônio Joaquim Rodrigues Jr. na Assembleia, em discurso sobre sua saída do ministério:

Exm. Amigo e colega conselheiro Rodrigues Jr. - peço licença a V. Ex. para dizer-lhe que com franqueza, mas respeitosamente, que seria um ato acertado a sua retirada do ministério. Coube a V. Ex. uma pasta alheia aos seus estudos e hábitos; daí, força é confessar, tem resultado notável na tibieza e falta de conveniente direção nos negócios da guerra. Peço-lhe mil desculpas por esta declaração, que, para mim é tanto mais dolorosa, quanto é elevada e sincera a estima que voto à pessoa de V. Ex., em que folgo de reconhecer um cidadão distinto e um correligionário digno de toda a consideração. Tenho a honra de ser com a maior estima: de V. Ex. amigo e colega muito afetuoso e obrigado. Lafayette Rodrigues Pereira. Rio, 29 de fevereiro de $1884^{17}$.

A atitude do presidente do Conselho desagradou aos parlamentares e aos outros ministros que viram a conduta como desrespeito ao partido. A carta demissionária escrita pelo próprio Lafayette surpreendeu a todos na Assembleia, pois "pela primeira vez se assistia a uma cena tão singular e imprevista. Um presidente de Conselho de Ministros despedir do Gabinete um seu colega, imputando-lhe incúria e incapacidade para ocupar a pasta que lhe fora confiada!” (PEREIRA DA SILVA, 2003, p. 519-527). Até então, nenhum ministro havia sido dispensado dessa forma, o que provocou protestos também da oposição e, novamente, conservadores e liberais se uniram contra outro chefe de governo. A capa do periódico representou a demissão do ministro da guerra com os personagens Lafayette Pereira, a mãe que deu a luz à Antônio Rodrigues Junior, o filho rejeitado, nascido daquele governo e que estava sendo colocado na roda dos expostos com sua carta de demissão.

\footnotetext{
${ }^{17}$ Anais da Câmara dos Deputados, 06 de maio de 1884.
} 
O "Penacho": os presidentes do Conselho de Estado e a Primeira Câmara dos Deputados por eleição direta

\section{Figura 7}

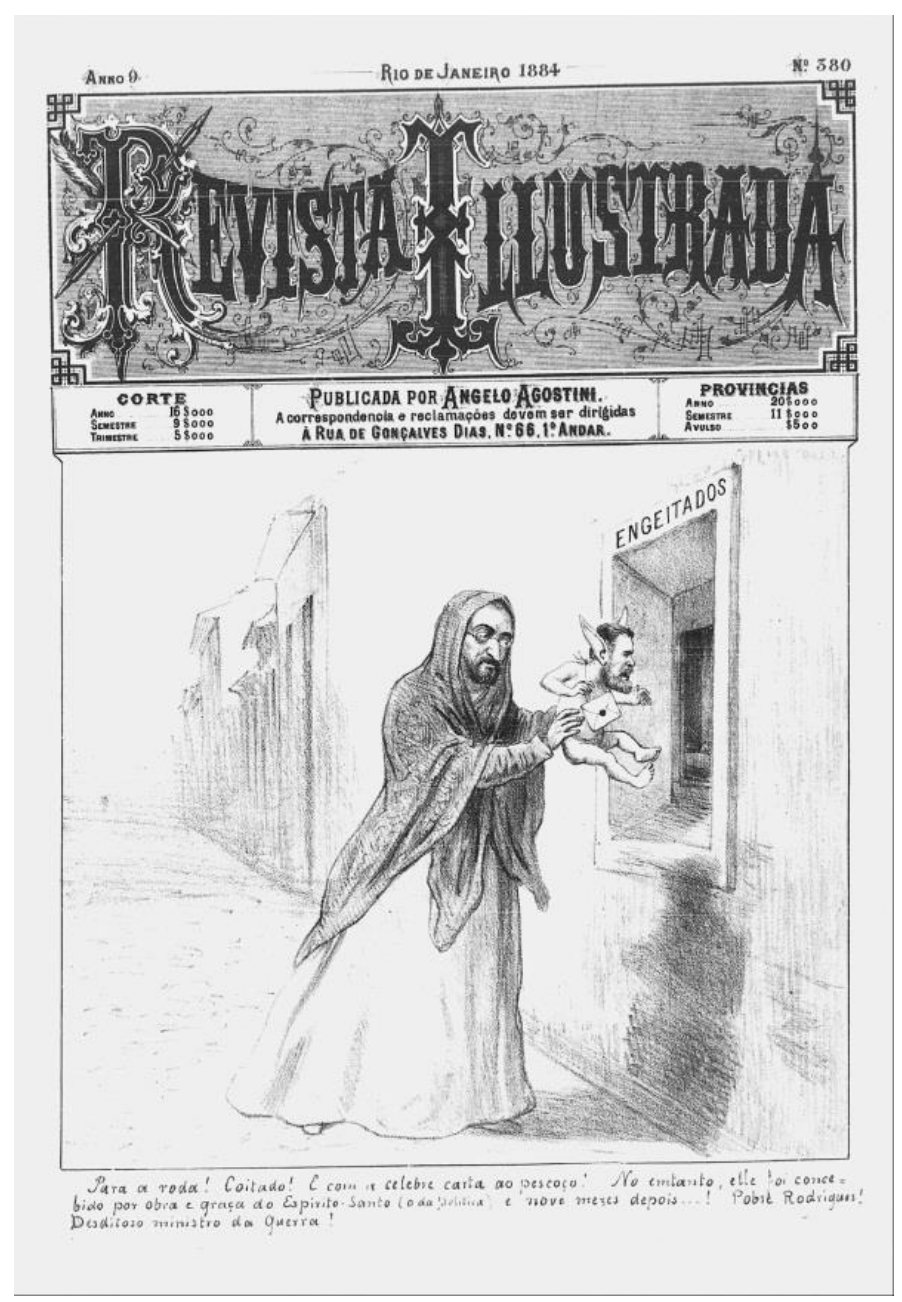

Fonte: Revista Illustrada, ano 9, 1884, nº 380.

Os últimos episódios contribuíram para que Lafayette perdesse o apoio de vez e um de seus correligionários, o deputado Zama (PL-BA), apresentou uma moção de desconfiança à Câmara, pela qual requeria a troca de ministério por julgá-lo sem prestígio para prosseguir. Após a leitura do requerimento, os deputados reivindicaram votação nominal. O requerimento foi aprovado, porém, a moção foi derrotada por 60 votos contra 56. No entanto, a vitória apertada de Lafayette sinalizou que ele não teria força parlamentar para permanecer à frente do ministério, e optou pela demissão ${ }^{18}$.

\footnotetext{
${ }^{18}$ Anais da Câmara dos Deputados, 03 de junho de 1884.
} 
O "Penacho": os presidentes do Conselho de Estado e a Primeira Câmara dos Deputados por eleição direta

(1881-1884) - Alexandra do Nascimento Aguiar

\section{MANUEL PINTO DE SOUZA DANTAS: UM “HOMEM PARTIDÁRIO”}

Manoel Pinto de Souza Dantas já havia recusado o convite para organizar o ministério, porém se viu pressionado a fazê-lo após a saída de Lafayette Rodrigues Pereira. O gabinete Dantas foi identificado ao abolicionismo, embora ele próprio não se visse assim, pois apenas considerava necessário que o Estado tomasse a frente do movimento, que já havia conquistado ampla adesão popular (COSTA, 1998, p. 476).

Em 09 de junho, Dantas se apresentou como presidente do Conselho e, com um discurso direto, enfatizou que a recuperação financeira e a emancipação eram as prioridades de seu governo. Segundo ele, adotaria maior rigor no orçamento através da redução de despesas e da arrecadação, neste caso, sentia-se forçado a recorrer à criação de novos tributos para elevar a receita do Estado $^{19}$. O anúncio sobre o aumento de impostos desagradou ainda mais porque seria adotado como recurso para dar continuidade à política de emancipação:

Dantas: Chegamos, Sr. Presidente [da Câmara], a uma quadra em que o governo carece intervir com a maior seriedade na solução progressiva deste problema, trazendo-o francamente para o seio do parlamento, a quem compete dirigir-lhe solução. (apoiados; muito bem) Nesse assunto, nem retroceder, nem parar, nem precipitar. [...]

É dever imperioso do governo, auxiliado pelo poder legislativo, fixar a linha até onde a prudência nos permite, e a civilização nos impõe chegar, sendo que assim se habilitará a coibir desregramentos e excessos, que comprometem a solução do problema, em vez de adianta-la ${ }^{20}$.

O discurso repercutiu para os abolicionistas como promessa de que a questão não se limitaria aos debates e entraria no plano da ação. A Revista Illustrada expressou essa expectativa sobre o Gabinete Dantas, retratando o presidente do Conselho na manobra do manche do barco de seu governo, "6 de junho", dia em que tomou posse, singrando entre os deputados antiabolicionistas, as pedras que lhe seriam o obstáculo. Provavelmente, uma referência aos deputados que fizeram oposição como os conservadores Andrade Figueira e Ferreira Viana e o deputado liberal Souza Carvalho, cujas falas serão analisadas no decorrer do artigo.

\footnotetext{
${ }^{19}$ Anais da Câmara dos Deputados, 09 de junho de 1884.

${ }^{20}$ Ibid.
} 
O "Penacho": os presidentes do Conselho de Estado e a Primeira Câmara dos Deputados por eleição direta

\section{Figura 8}

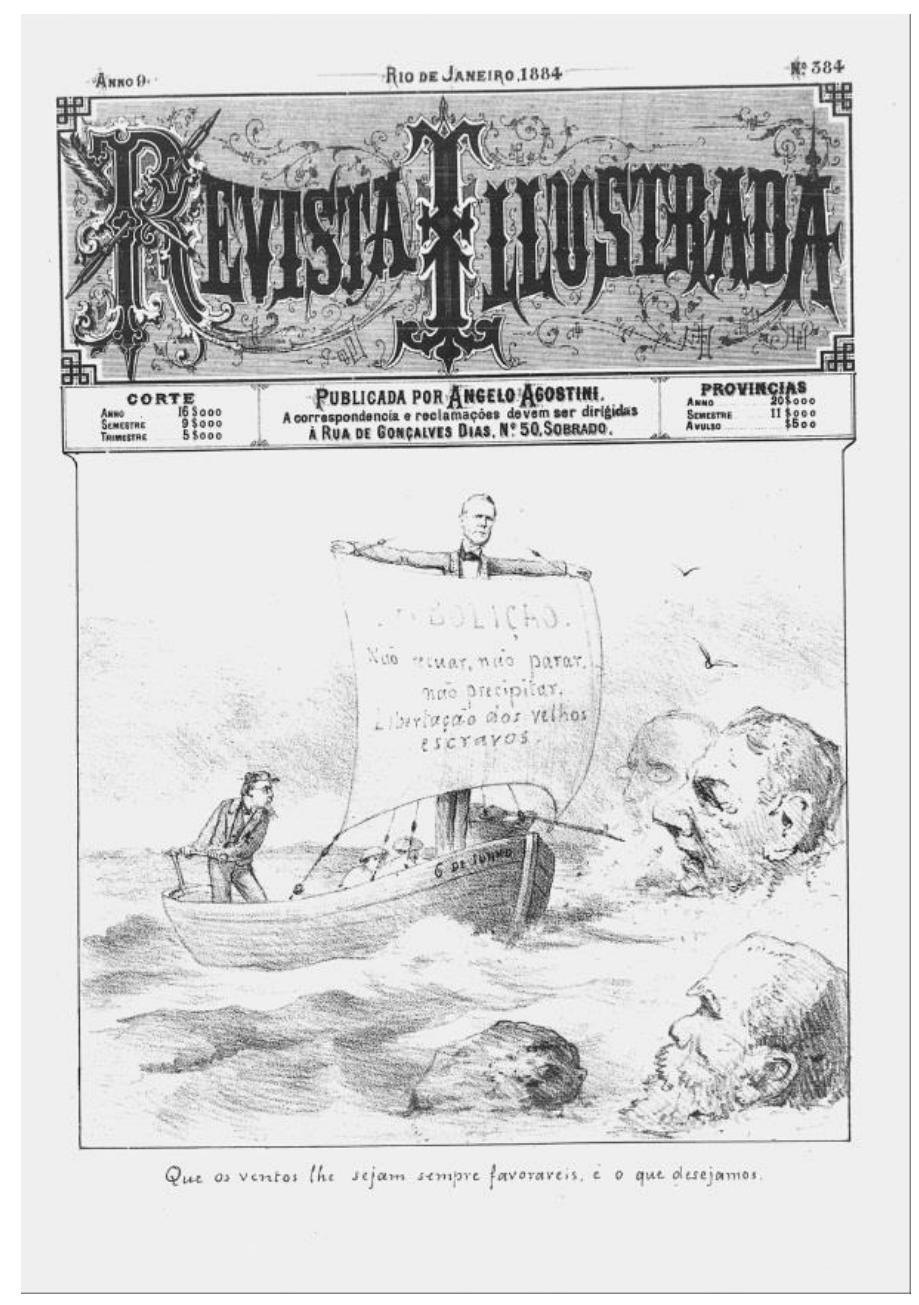

Fonte: Revista Illustrada, ano 9, 1884, $\mathrm{n}^{\circ} 384$.

Mesmo mencionando que a emancipação respeitaria o direito dos proprietários de escravos, o governo forçava a desvalorização destes como mercadoria através de taxações e medidas de controle sobre a propriedade escrava, como a localização provincial do escravo; e visava ampliar o fundo de emancipação com o lançamento de um imposto nacional, que seria pago também por não proprietários. Evidenciando que o governo não pouparia esforços para avançar com a questão servil, Dantas anunciou a elaboração de um projeto para libertar os escravos a partir dos sessenta anos de idade.

A primeira reação da oposição partiu de Antônio Ferreira Vianna (PC-RJ), que fez uma provocação ao chamar a atenção sobre a leitura do programa de governo por Dantas, o que fugia à regra dos discursos ministeriais, "o nobre presidente do Conselho teve uma vantagem de que não posso usar: escreveu para ler, eu sou compelido a falar para ser lido". O deputado ressaltou a dificuldade do Partido Liberal em organizar um ministério e que a 
O "Penacho": os presidentes do Conselho de Estado e a Primeira Câmara dos Deputados por eleição direta (1881-1884) - Alexandra do Nascimento Aguiar

insistência do Imperador sobre Saraiva era por não identificar em nenhum outro ministro alguém com habilidade para sustentar a reforma eleitoral. D. Pedro II procurava "o pensamento do homem e não o desejo do partidário", por isso, estava sem sucesso nas nomeações dos liberais.

Para os conservadores, o governo deveria se ocupar da economia à qual todas as outras questões estavam subordinadas, especialmente a emancipação. A questão era considerada como interesse oportunista dos liberais para agradar a opinião pública, "porque entendem que é melhor transigir com os interesses de ocasião, com as conveniências partidárias, do que elevar-se a altura das necessidades do Estado" 21 . Se o governo não conseguia elaborar planos para redução de déficits, também não tinha autoridade para cobrar impostos e dispor dos recursos públicos. Nesse ponto, Ferreira Vianna afirmou que assim como não pagaria novos impostos, também lideraria uma resistência constituída por cidadãos contribuintes.

O deputado defendia a ideia de que a economia do Estado deveria se apoiar sobre "os princípios liberais na organização administrativa", descentralizar e distribuir as despesas e o crédito entre as províncias e os municípios. Mas, ele afirmava que via apenas o desequilíbrio entre os recursos empregados pelo governo e a produção que era menor. Citava, como exemplo, as ferrovias, um excesso de despesas porque a arrecadação era inferior aos gastos para a construção, além de contribuírem para dispersar a população e empobrecê-la mais. As estradas de ferro e outros melhoramentos deveriam ser encargos das províncias, pois, dentro da lógica centralizadora, os contribuintes que nunca dispuseram de estradas de ferro para escoar seus produtos pagavam por elas ${ }^{22}$.

A emancipação do escravo foi o segundo tema analisado por Ferreira Vianna, que percebia apenas duas vias de solução: "a da lei ou a da revolução. Ou um partido toma a responsabilidade de uma revolução e desfecha o golpe, ou tem de obedecer à lei existente e melhorá-la progressivamente até extinguir o mal". Recuperar a economia era o primeiro passo para a emancipação, o contrário resultaria em guerra civil e falência. O deputado refutava a concessão da liberdade como direito natural acima do direito civil - leia-se direito de propriedade - e argumentava:

Senhores, esta questão pode ser encarada de dois modos: ou considerando o homem escravo, ou considerando unicamente o Estado. Os homens políticos dos Estados Unidos entendiam que a República não fora feita para negros, e,

\footnotetext{
${ }^{21}$ Ibid.

${ }^{22}$ Anais da Câmara dos Deputados, 09 de junho de 1884.
} 
O "Penacho": os presidentes do Conselho de Estado e a Primeira Câmara dos Deputados por eleição direta

(1881-1884) - Alexandra do Nascimento Aguiar

por conseguinte, que deveriam extirpar a escravidão. Pouco se importando com o escravo. Entendo, porém que devemos importar-nos com o escravo, que é nosso irmão em Jesus Cristo e progressivamente destruir a escravidão; não faço uma hecatombe do meu semelhante para excluir do Império esta instituição ${ }^{23}$.

O deputado conservador sustentava que a solução dos problemas econômicos deveria preceder a busca por solução para o trabalho escravo, e sem novas tributações. A defesa da opinião do Partido Conservador sobre a questão servil aparecia como majoritária e, assim, colocava em evidência as rachaduras do Partido Liberal sobre o tema, como exemplificado pelo apoio aos conservadores dado pelo deputado governista Antônio Alves Souza Carvalho (PL-PB), abrindo a possibilidade para novas coalizões:

Ferreira Vianna: Aquele que apressar a reorganização e estabilidade das nossas finanças terá avançado e paralelamente na resolução servil. Querer resolver esta questão antes da primeira, seria prejudica-la e lançar o país no perigo duplo da guerra civil e da bancarrota. (apoiados)

Quem, com responsabilidade própria, homem pensador, ousará, publicamente, dizer que quer a emancipação já e já, como um consagração do direito natural, apesar do direito civil? Haverá alguém que pretenda isso?

Sousa Carvalho [PL-PB]: só os malucos e perversos.

Severino Ribeiro [PC-RS]: há muita gente que o queira sem ser maluco nem perverso. [...] Os abolicionistas têm uma opinião como outro qualquer, deve ser respeitada.

Andrade Figueira [PC-RJ]: como V. Ex. não a tem, permita que apoiemos as palavras do nobre deputado pela Paraíba ${ }^{24}$.

Os conservadores também desconfiavam das intenções do Presidente do Conselho sobre dar continuidade à política conciliatória retomada pela reforma eleitoral de 1881. Para a oposição, Dantas não estava preocupado em manter essa neutralidade porque queria, acima de tudo, preservar seu partido no poder, por isso privilegiaria grupos que o apoiassem no Parlamento,

Ferreira Vianna: O nobre presidente do Conselho assegurou que seria imparcial administrador, e que, se por ventura o seu ministério existisse até a época das eleições... [...] Sr. presidente, o ministério tem cor política tão acentuada, seus membros compromissos tais, que é difícil convencer ao país desta prometida imparcialidade. [...] Enfim o nobre presidente do Conselho é aceito e é considerado como homem partidário.

Dantas: Já fui; hoje estou afastado completamente da direção imediata do Partido Liberal da Bahia; não tenho a direção dele. Sou homem político, mas não sou partidário. Tenho pressa em fazer essa declaração $0^{25}$.

\footnotetext{
${ }^{23}$ Ibid.

${ }^{24}$ Ibid.
} 
O "Penacho": os presidentes do Conselho de Estado e a Primeira Câmara dos Deputados por eleição direta

(1881-1884) - Alexandra do Nascimento Aguiar

A questão escravista provocava dissensões no meio liberal, ao contrário do Partido Conservador, cujo discurso coeso subordinava a reforma às condições da economia. $\mathrm{O}$ argumento também era adotado pelos liberais refratários à ideia e funcionava para postergar novas medidas sobre a emancipação. Diante dessas divisões internas, os conservadores se fortaleciam e esperavam a oportunidade para retornar ao poder e, nas palavras de Ferreira Vianna, a oportunidade resumia a grande política ${ }^{26}$.

A dissonância entre o Poder Executivo, representado pelo Gabinete, e a Câmara dos Deputados se agravou sob a presidência de Dantas quando o projeto de emancipação foi anunciado para entrar em discussão ainda naquela legislatura. $\mathrm{O}$ acontecimento ganhou destaque na capa da Revista Illustrada: nesta, Manuel Dantas se esconde por trás de Rodolfo Epifânio Dantas (PL-BA), seu filho, e segura o projeto como se fosse apresentado ao Parlamento pelas mãos do jovem deputado, enquanto o periódico coloca uma grande coroa de louros na cabeça de ambos, pai e filho.

\section{Figura 9}

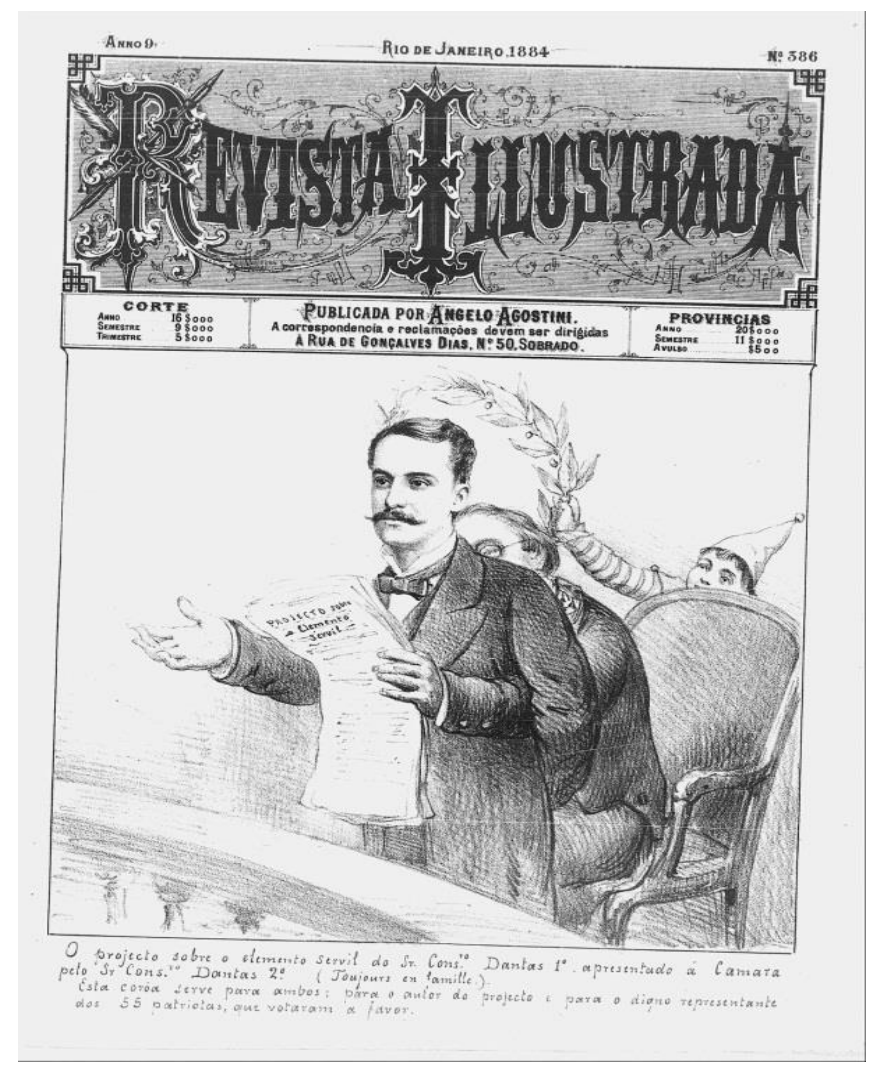

Fonte: Revista Illustrada, ano 9, 1884, $\mathrm{n}^{\mathbf{0}} 386$.

\footnotetext{
${ }^{25}$ Ibid.

${ }^{26}$ Ibid.
} 
O "Penacho": os presidentes do Conselho de Estado e a Primeira Câmara dos Deputados por eleição direta (1881-1884) - Alexandra do Nascimento Aguiar

O projeto de libertação dos sexagenários apresentado pelo deputado Rodolfo Dantas (PL-BA) instituía a libertação dos escravizados a partir dos 60 anos de idade e abria outras possibilidades como por omissão de matrícula e por transgressão do domicílio legal do escravizado e o já conhecido fundo de emancipação. O liberto que desejasse permanecer na casa de seu senhor deveria ser vestido e alimentado por ele, neste caso, sem obrigatoriedade de remuneração e caso optasse por sair da proteção do seu senhor, poderia contar com o Estado para seu sustento através do juizado de órfãos. Além disso, o projeto estabelecia a rematrícula de escravos e o pagamento de uma taxa por cada um, parte desse valor seria destinado para o fundo de emancipação. A proposta visava ainda a localização do escravizado, que não poderia ser transferido para outra província, o que resultaria na libertação deste exceto nos casos de fuga ou de mudança de domicílio pelo proprietário. $\mathrm{Na}$ matrícula, este deveria declarar o valor do escravo e que seria também seu preço de alforria pelo fundo de emancipação; para que não houvesse tentativa de exceder o valor e dificultar a libertação, o projeto estipulava um teto de preço de acordo com a idade dos escravos ${ }^{27}$.

Os debates sobre o orçamento eram utilizados para enfraquecer o governo e se tornaram inconciliáveis, os deputados que faziam oposição à Dantas, incluindo os liberais, criaram obstáculos para que ele pudesse prosseguir. O pedido de demissão por Antônio Moreira de Barros (PL-SP) da Presidência da Câmara dos Deputados reforçou a vulnerabilidade do Gabinete, pois foi uma reação em protesto ao projeto de libertação dos escravos sexagenários. A demissão recebeu a votação de 55 deputados favoráveis e 52 contrários, a pequena diferença de apenas três votos significou a prévia da desestabilização e não a vitória do governo. Formou-se nova divisão dentro dos liberais, e os conservadores passaram para o lado de Moreira de Barros.

Pouco mais de uma semana após o episódio, o deputado Lourenço Cavalcanti de Albuquerque (PL-AL) apresentaria uma moção de desconfiança, "a Câmara dos Srs. deputados condena as principais ideias do projeto sobre o elemento servil" ${ }^{\prime 2}$. Os deputados contrários à política de emancipação do Gabinete Dantas venceram com 59 votos, dos quais 17 eram liberais que, desde 1882, derrubavam seus próprios Gabinetes (GERSON, 1975, p. 277), compondo com o Partido Conservador. Diante do impasse entre o Parlamento e o Executivo acerca do projeto de libertação dos sexagenários, e que inviabilizaria os trabalhos

\footnotetext{
${ }^{27}$ Anais da Câmara dos Deputados, 15 de julho de 1884. Projeto no 48 - 1884. Elemento servil.

${ }^{28}$ Anais da Câmara dos Deputados, 28 de Julho de 1888.
} 
O "Penacho": os presidentes do Conselho de Estado e a Primeira Câmara dos Deputados por eleição direta (1881-1884) - Alexandra do Nascimento Aguiar

parlamentares, Dantas pediu autorização ao Imperador para dissolver a Câmara dos Deputados, antecipando o fim daquela legislatura em $1884^{29}$.

\section{CONSIDERAÇÕES FINAIS}

A Revista Illustrada desenhou o cenário político criado pela Lei Saraiva que prometia a renovação política. As representações sobre a atuação dos presidentes de Conselho demonstraram resultados que contradizem tal expectativa: a eleição de uma Câmara majoritária de escravistas; o silenciamento de deputados progressistas e a crescente fragilização do governo liberal, desgastado gradativamente, de dentro para fora, e, principalmente, as tentativas de levar o debate sobre a emancipação de volta para o Plenário, dessa vez pela pressão das ruas.

O Partido Liberal atingiu o propósito esperado com a reforma eleitoral de 1881, nessa primeira legislatura - oposição e situação lado a lado dentro do Parlamento -, todavia, o resultado bem sucedido foi prejudicial para a governabilidade do próprio partido. O número expressivo de deputados da oposição era suficiente para obstaculizar a execução do programa liberal e a aprovação de projetos que desagradavam aos conservadores. As coalizões de conservadores e liberais demonstram uma visão de mundo comum entre os deputados das duas legendas e que diluía as distinções ideológicas, pois tais articulações expressavam a dinâmica da defesa de interesses de grupo e de família acima das distinções partidárias como orientação dos debates sobre assuntos públicos. Deputados liberais contribuíram para derrubar Gabinetes de seu partido e se mostraram divididos sobre o próprio programa partidário.

As dissensões intrapartidárias e as convergências com a oposição cresciam à medida que os Gabinetes de Martinho Campos, do Visconde de Paranaguá, de Lafayette Pereira e Manuel Dantas eram organizados como tentativas de preencher o vazio de liderança deixado pela demissão de Saraiva. Os Presidentes do Conselho era substituídos a partir da rejeição sofrida pelo Gabinete anterior e ofereciam propostas conflitantes como governo para conseguir o apoio do Parlamento, não dialogavam entre si como representantes do mesmo partido. As divergências dentro dos liberais se refletiam na queda dos ministérios e na demissão dos presidentes da Câmara, como nos casos de Martim Francisco (PL-SP) e Moreira de Barros (PL-SP), em desacordo com os Gabinetes.

\footnotetext{
${ }^{29}$ Anais da Câmara dos Deputados, 03 de setembro de 1884. 
As trocas de ministérios entre 1881 e 1884 expressavam a fragmentação do Partido Liberal diante da pluralidade de questões de seu programa. Alguns temas eram consenso entre os correligionários, como a descentralização político-administrativa, também atraente para uma parcela dos conservadores. Outras reformas perderam força, como o fim da vitaliciedade do Senado e do Conselho de Estado, enfraquecidas pelo ingresso de liberais nos quadros do Senado e do Conselho na mesma proporção de conservadores, além da entrada de republicanos assumidos como Lafayette Rodrigues. Eram reformas pensadas sob a retomada de poder pelos conservadores e sob a crise política de 1868 e que não no quadro político da década de 1880.

\section{FONTES}

Anais da Câmara dos Deputados, 30 de Junho de 1882.

Anais da Câmara dos Deputados, 05 de julho de 1882.

Anais da Câmara dos Deputados, 14 de maio de 1883.

Anais da Câmara dos Deputados, 26 de maio de 1883.

Anais da Câmara dos Deputados, 06 de maio de 1884.

Anais da Câmara dos Deputados, 03 de junho de 1884.

Anais da Câmara dos Deputados, 09 de junho de 1884.

Anais da Câmara dos Deputados, 15 de julho de 1884. Projeto nº 48 - 1884. Elemento servil.

Anais da Câmara dos Deputados, 28 de Julho de 1888.

Anais da Câmara dos Deputados, 03 de setembro de 1884.

Constituição Política do Império do Brasil (de 25 de março de 1824)

O Conservador, 24 de fevereiro de 1882.

Revista Illustrada, ano 7, 1882, nº 283.

Revista Illustrada, ano 7, 1882, nº 284.

Revista Illustrada, ano 7, 1882, n 289.

Revista Illustrada, ano 7, 1882, nº 290.

Revista Illustrada, ano 7, 1882, no 308.

Revista Illustrada, ano 9, 1884, no 378.

Revista Illustrada, ano 9, 1884, no 380.

Revista Illustrada, ano 9, 1884, n 384.

Revista Illustrada, ano 9, 1884, no 386. 
O "Penacho": os presidentes do Conselho de Estado e a Primeira Câmara dos Deputados por eleição direta

(1881-1884) - Alexandra do Nascimento Aguiar

\section{REFERÊNCIAS BIBLIOGRÁFICAS}

ALONSO, Ângela. Flores, votos e balas. O movimento abolicionista brasileiro (1868-1888). São Paulo: Companhia das Letras, 2015.

CARVALHO, José Murilo de. A construção da ordem: a elite política. Teatro de sombras: a política imperial. $4^{\circ}$ ed. Rio de Janeiro: Civilização Brasileira, 2008.

COSTA, Emilia Viotti. Da senzala à colônia. $4^{\mathrm{a}}$ ed. São Paulo: Fundação Editora da UNESP, 1998.

GERSON, Brasil. A escravidão no Império. Rio de Janeiro: Pallas, 1975.

GRAHAM, Richard. Clientelismo e política no século XIX. Rio de Janeiro: Editora da UFRJ, 1997.

HOLANDA, Sergio Buarque. O Brasil monárquico. Tomo II, v. 7. Do Império à República. $8^{\text {a }}$ Ed. Rio de Janeiro: Bertrand Brasil, 2008.

KOSERITZ, Carl Von. Imagens do Brasil. Belo Horizonte: Ed. Itatiaia; São Paulo: Editora da Universidade de São Paulo, 1980.

MARTINS, Maria Fernanda Vieira. A velha arte de governar: o Conselho de Estado no Brasil Imperial. Topoi, v. 7, n. 12, p. 178-221, 2006.

A velha arte de governar: um estudo sobre política e elites a partir do Conselho de Estado (1842-1889). Rio de Janeiro: Arquivo Nacional, 2007.

PEDREIRA, Jorge. COSTA, Fernando Dores. D. João. Um príncipe entre dois continentes. São Paulo: Companhia das Letras, 2008.

PEREIRA DA SILVA, João Manuel. Memórias do meu tempo. Pelo conselheiro João Manuel Pereira da Silva. Brasília: Senado Federal, Conselho editorial, 2003.

PEREIRA, Lafayette Rodrigues. Cartas ao irmão. São Paulo: Companhia Editora Nacional, 1968.

SOUSA, Álvaro Paulino Soares de. Três brasileiros ilustres: José Antônio Soares de Sousa, Visconde de Uruguai e Conselheiro Paulino José Soares de Sousa. Contribuições biográficas por ocasião do centenário da independência. Rio de Janeiro, typo. Leuzinger, 1923.

Recebido em: 31/05/2018

Aprovado em: 27/07/2018 